Studies in African Linguistics

Volume 30, Number 1, Spring 2001

\title{
A TONAL SPLIT IN BOUND ARGUMENT PRONOUNS \\ IN IL-KEEKONYOKIE MAA
}

\author{
Kent Rasmussen \\ University of Oregon
}

This paper describes and accounts for the tonal split between bound argument prefixes of Il-Keekonyokie Maa verbs with (apparently) High and Low tone. Data with the tonal split are given, followed by an analysis showing that the apparent High tone must be lexically unspecified for these prefixes. This analysis is required because a lexical High prefix tone in certain verbs would cause downstep, where downstep is not observed. Neutralization of the tone split is then considered, with the data presented and accounted for by an analysis for each of the two verb root classes. The conclusion discusses the need for the apparent word initial High tone to be spread from the stem tone.

\section{Introduction ${ }^{1}$}

A tonal split between first and second person verb forms, on the one hand, and third person verb forms on the other, has been observed in all three branches (Western, Eastern, and Southern) of the Nilotic languages. ${ }^{2}$ My intention here is not to prove such a split for all of Nilotic, but to show how that split is evidenced in Il-Keekonyokie Maa, ${ }^{3}$ a dialect area of Maa, an Eastern Nilotic language spoken

1 The data in this paper are from the Il-Keekonyokie dialect of Maa, from the Narok area of Kenya. Most of it is from Sarah Tuukwo, but often checked with Leonard Ole-Kotikash. Underlined data are from the Il-Wuasinkishu dialect, from Wilson Ole-Nayomah. While most of the data was collected by me, some of the data is from Doris Payne's field notes, and all of it was collected under her academic and financial support (NSF grant SBR-9616482). Fieldwork in Kenya was conducted under Kenya research permit \#OP/13/001/23C28. I am grateful to Keith Snider for the initial brainstorming that led to this analysis, Doris Payne for comments on various versions of this paper, and to Gerrit Dimmendaal for some general perspec-tives on Nilotic tone.

2 I thank Gerrit Dimmendaal for this observation; an overview of data showing this split is given in section 1.1.

3 I use this term for the data I will describe, acknowledging an unknown variation among those that speak what has been referred to in the literature as Maa. I am confident that this analysis covers this dialect area, and probably more, but I would not want to speak for all Maa dialect areas (other dialect areas of the Maasai, Samburu, Chamus) at this time. I have already noticed consis...continued on next page 
in Kenya and Tanzania. Describing this split in Il-Keekonyokie Maa and providing a coherent analysis are the purpose of this paper. I first show data that evidences the split. I then show several analyses with lexical forms that might account for the split, and show the superior one to be that which analyzes the apparently High prefixes (e.g., first person singular) to be lexically unspecified for tone. After showing data which evidences a neutralization of this split, I delimit the scope of the split, showing that the split is neutralized for two-mora words, though for at least two independent reasons.

1.1. A survey of the split in several Nilotic languages. 4 The Nilotic Languages can be broken up into three branches: Eastern, Southern, and Western [Grimes 2000, Greenberg 1963]. This section will show evidence for a split between the person markers in each of these three branches of Nilotic. I do not claim that this split is evidenced throughout the grammar of each of the three languages illustrated below, but that the split is present at least in the given data. Turkana (Eastern Nilotic) data, illustrated in (1)-(3), are as given in Dimmendaal [1983:121122], with his glossing and abbreviations retained (He indicates that prefixes mark person, but not number). The tone over the root provides evidence of a tonal split, with the High tone pushed one mora to the right in the third person form; the nonsubject morphology in the verb in each of (1)-(3) is the same.

Turkana
(1) à-lós-ì á-ỳ̀̀
I-go-A I(N)
'I will go'
(2) ì-lós-ì í-yòn
you-go-A you(N)
'you will go'
(3) è-lòs-î yèsi
3-go-A he(N)
'he/she/it will go'

A similar split is indicated for non-past verbs in Toposa, closely related to Turkana, in data presented in Schröder [1989:131-2]. Here again (Table 1), the split is seen in the tone over the root, pushing the High tone onto the suffix in the third person form. The non-subject morphology is again constant in each column, so the split in tone is again due to the subject.

Lango (Western Nilotic) also shows a tonal split as illustrated in Table 2, which gives paradigms for several of the tense/aspects, as given in Bavin [1980.91]. Again the tone for first and second person singular forms is the same, and different from third person singular. While there is more variety than in the Eastern Nilotic

tent deviation from this data in a speaker of another Maa dialect area (Il-Purko), but I do not have sufficient data to describe those correspondences at this time. Therefore, this analysis may or may not cover data from other dialect areas, even among what is called Maasai.

4 The orthography in this paper follows Tucker and Mpaayei [1955; hereafter TM], with three exceptions: 1) $I, \varepsilon, \supset$, and $v$ for the -ATR vowels; 2 ) tone marking on all vowels, with 'á for TM's 'mid' or Downstepped High tone, and 3) $y$ and $w$ for non-moraic $i / I$ and $w / v$. While the last convention loses ATR information, it preserves moraic structure, which is essential for understanding tone; ATR is generally predictable from surrounding vowels. Throughout the text, capitalized High/Low or $\mathrm{H} / \mathrm{L}$ is used when referring to phonemic tones, lowercase high/low when referring to surface pitch patterns. 
Table 1. Toposa non-past paradigms with 1, 2 vs. 3 person tone split

\begin{tabular}{|c|c|c|c|}
\hline \multicolumn{4}{|c|}{ ASPECT/VOICE } \\
\hline & $\begin{array}{l}\text { Imperfective } \\
\text { '(to) weed' }\end{array}$ & $\begin{array}{l}\text { Perfective } \\
\text { '(to) herd' }\end{array}$ & $\begin{array}{l}\text { "Reflexive-medial" } \\
\text { '(to) shave' }\end{array}$ \\
\hline $1 \mathrm{~S}$ & à-cáp-ì & à-twár-ìt & à-bány-à \\
\hline $2 S$ & ì-cáp-ì & ì-twár-ìt & ì-bány-à \\
\hline $3 S$ & $\grave{\varepsilon}$-càp-ì & $\grave{\varepsilon}$-twàr-ìt & غ̀-bàny-à \\
\hline
\end{tabular}

Table 2. Lango paradigms with 1, 2 vs. 3 person tone split (with 'to read')

\begin{tabular}{cllll}
\multicolumn{4}{c}{ Past } & \multicolumn{2}{c}{ TENSE/ASPECT } \\
\multicolumn{1}{c}{ Progressive } & Future \\
1S & àkwánò & intr. & trans. & intr. \\
2S & ìkwánòn & ákwàn & ákwànnò & ábínó kwàn \\
3S & òkwànònnò & àkwán & àbínó kwàn \\
& & àkwànnò & àbínó kwàn
\end{tabular}

data above, the difference generally amounts to High on first and second persons, and Low on third.

Nandi (Southern Nilotic) also shows this split, according to paradigm tables given in Creider and Creider [1989.77, 83]. Table 3 shows their indicative non-past tense forms for both classes of verbs, those with the k $\grave{\varepsilon} \dot{\varepsilon}$ - prefix and those with the kì̀- prefix. The table uses their tense/aspect labels. Like the Lango data, the contrast here may be more difficult to see because of the variety of tone patterns, but there is clearly an identity between the first and second person forms, and a distinction between these forms and the third person forms.

1.2. The split, and neutralization, in Il-Keekonyokie Maa. The same split seen in other Nilotic languages is also seen in Il-Keekonyokie Maa verb forms, as in (4)(6). 5 In these data, the contrast is seen on the first mora, with High on the first

5 The following abbreviations are used in this paper.

A

APAS

CAUS

DAT

FS

FP

INST instrumental applicative, class II causative

INTR intransitive

IT

MID

$1>2$ aspect

anti-passive

class I causative

dative applicative

feminine sing.

feminine plural

itive (motion away)/trans-locative

middle

$1 \mathrm{~S}$ subject acting on $2 \mathrm{~S}$
MS masculine singular

MP masculine plural

$\mathrm{N}$ nominative

PF perfect

RED reduplication

VENT ventive/cis-locative

1S, $2 S$ 1st person sing., 2nd, etc.

$1 \mathrm{P}$

2

3

II
1 st person plural

2nd person subject

3rd person subject

class II prefix 
Table 3. Nandi indicative non-past paradigms 6

Tense/aspect

\begin{tabular}{|c|c|c|c|c|c|c|}
\hline \multirow{3}{*}{$\begin{array}{l}\text { kè̀̀-kás } \\
\text { 'to listen' }\end{array}$} & \multicolumn{3}{|c|}{ perfective } & \multicolumn{3}{|c|}{ imperfective } \\
\hline & \multirow[t]{2}{*}{ simple } & \multicolumn{2}{|c|}{ perfect } & \multirow[t]{2}{*}{ simple } & \multicolumn{2}{|c|}{ perfect } \\
\hline & & non-simple & simple & & non-simple & simple \\
\hline is & ákàs & ààkàs & áàkàs & ákásé & àà & áà \\
\hline $2 S$ & Íkàs & İ̀kà & Îkàs & Íkásé & İIk & \\
\hline $3 \mathrm{~S}$ & kăs & kókâs & kókâs & káséy & kòkáséy & kókáséy \\
\hline $\begin{array}{l}\text { kì̀-kât } \\
\text { 'to greet' }\end{array}$ & & & & & & \\
\hline $1 \mathrm{~S}$ & áàkàt & áăkàt & áàkàt & áàkàtíí & ààkátíí & áàkátíí \\
\hline $2 S$ & Îkàt & Î́kàt & Îkàt & Îkátíí & İ̀kátíí & Îkátíi \\
\hline $3 \mathrm{~S}$ & Íkât & kóókât & kóókât & íkàtì & kòòkàtì & kóòkàtì \\
\hline
\end{tabular}

(4) á-gór-'isshó

1S-strangle-APAS

'I strangle.'

(5) í-gór-'íshó

2-strangle-APAS

'You(S) strangle.'

(6) è-gór-'íshó

3 -strangle-APAS

'He/she/it/they will strangle.'

person singular and second person forms, and Low on the third person form.

There is some difficulty, however, in observing this split in Il-Keekonyokie Maa because, in the simplest forms of almost all verbs, the split is neutralized. Tucker and Mpaayei [1955, hereafter TM.72] lay out the variety of bound argument pronouns for Il-Keekonyokie Maa, reproduced here in Table 4. Neutralization of the tonal contrast can be seen in the first, second, and third person singular forms with third person objects, all of which are High in tone on both syllables. However, TM gave no analysis of the bound argument prefixes given in Table 4 beyond the morpheme boundaries as shown. I will show in this paper that the pattern shown in Table 4 is not the unmarked tone pattern for Il-Keekonyokie Maa, but that it is a

$3>1 \quad 3$ subject acting on $1 \mathrm{~S}$

$3>2>1 \quad 3$ subject acting on $2 \mathrm{~S}$ or 2 subject acting on $1 \mathrm{~S}$

Note: $2 \& 3$ are not sensitive to number.

${ }^{6}$ Here the low falling tone in Nandi is indicated with the following symbol: $\hat{\mathrm{a}}, \hat{\mathrm{I}}$. 
Table 4. à-lám 'to avoid'

\begin{tabular}{|c|c|c|c|c|}
\hline \multirow{2}{*}{$\begin{array}{r}\text { SUBJECT } \\
\text { sing. }\end{array}$} & \multirow[b]{2}{*}{1} & \multicolumn{2}{|l|}{ OBJECT } & me (1S) \\
\hline & & á-lám & áá-lám & - \\
\hline & 2 & Í-lám & - & kí-lám \\
\hline & 3 & é-lám & kí-lám & áà-lâm \\
\hline pl. & 1 & kì-lâm & kì-lâm ìyíé & - \\
\hline & 2 & Í-lámílámà & - & kí-lámílámà \\
\hline & 3 & É-lám & kí-lám & áà-lâm \\
\hline
\end{tabular}

phonologically conditioned neutralization of a lexical split in tone between the first singular and second person bound argument pronouns and the third person bound argument pronouns.

In section 3, I provide an analysis for the split with consistent lexical representations that covers the data we have for Il-Keekonyokie Maa. Section 4 then describes the neutralization in detail, while section 5 provides an analysis accounting for the neutralization which covers all cases.

By way of further introduction to these bound argument pronouns, Table 4 shows the third person singular and plural forms to be identical, and this is true for all non-perfect forms. The second person forms have the same argument prefix, with number of subject only distinguished by reduplication in the plural stem. The first person forms, on the other hand, have an entirely different prefix for the plural. Also, the two rightmost columns of Table 4 compose an inverse system which is triggered whenever a speech act participant (1S or $2 \mathrm{~S})$ is the grammatical object of the clause (see Payne et. al. [1994] for a complete analysis).

1.3. Assumptions and scope of this paper. Il-Keekonyokie Maa has two tones and downstep that only occurs in phrase final position (TM.167). There is a falling tone which also occurs only phrase finally (TM), but which is likely compositional, rather than an independent toneme. The TBU in Maa is the mora [Levergood 1990], and the phrase-final High-Low falling tone is the only case where more than one tone associates to a given mora. I will assume that tone association and subsequent spreading (iterative to empty TBUs) operate from right to left.

I will focus on forms in a single aspect, which TM call "present tense". This aspect, which is morphologically unmarked, is called "non-perfective" by Christa König [1993] (see also Payne [1995]), but there is some indication that the aspect she calls "perfective" includes perfect readings as well. For the sake of having a consistent label, I will refer to the morphologically unmarked aspect as "nonperfect", and the marked aspect as "perfect".

The tonal split described in this paper likely includes several of the prefixes in Table 4; the prefixes with a second person singular object and first person (áá-lám) and third person (kí-lám) subjects appear to pattern just like the first person 
singular and second person prefixes. However, this paper will focus on the contrast between the first person singular and third person prefixes, only occasionally including data with second person subjects and these inverse prefixes. ${ }^{7}$

A third category of prefix that will be ignored entirely in this paper includes the third person acting on first person singular (áà-lâm) and the first person plural (kìlâm), which may eventually be shown to have an initial High-Low tone contrast on the prefix.

In Il-Keekonyokie Maa, as in other Nilotic languages, there are two morphological classes of verbs, with Class II distinguished by an obligatory I- prefix. This Class II prefix is not synchronically analyzable in Il-Keekonyokie Maa. It is obligatory on Class II roots, is unacceptable on Class I roots, and does not have any transparent component of meaning (e.g., à-súj 'to follow' vs. à-y-súj'to wash'). The two classes also take different tone patterns in certain derivations (see Rasmussen [in preparation] for details). Because there is a tonal distinction between the two morphological classes, and because the prefix devocalizes, one would expect a consistent effect on the tone of words with Class II stems. The effect is not as consistent as one might like in the data currently available, however, so I will save a fuller discussion until it has been worked out in detail.

Because this paper investigates the tonal split in argument prefixes, I take an admittedly naïve view of the tone in the lexical representations of non-argument verb morphology. I assume that prior to inflection of the verb stem with bound argument pronouns, underlying tones are contributed to the verb stem by the lexical forms of the derivational morphemes in the word. In addition, I assume that there is a contribution of a non-perfect/indicative High tone for verb forms that have no apparent lexical source of High tone, since every available non-perfect, indicative verb form has at least one High tone in the word, regardless of the stem morphology. I refer to the combination of Class prefix, root, and other nonargument morphology in a given aspect/mood as "the stem". I take the "stem tone" to be the portion of the surface form that does not vary between first person singular and third person forms and I use this stem tone as the input for my derivations. For example, in (7), the arguments are indicated by the prefixes a- (1S)

(7) a. á-ytá-bél-'íshó.

( $\mathrm{HHH}$ !HH)

1S-CAUS-break-APAS

'I will make people break.'

b. $\grave{\varepsilon}-y t \grave{c}-b \varepsilon ́ l-' I s h o ́$.

3-CAUS-break-APAS

'He/she/it/they will make people break.'

\footnotetext{
7 Unfortunately, I do not have carefully checked data available to prove this analysis for all these prefixes, though all the data I have with them is in accordance with the analysis presented in this paper, so it is likely a matter of collecting and presenting the data before they, too, will submit to this same analysis.
} 
and $\varepsilon$ - (3), so the non-argument (i.e., stem) morphology includes yta-bcl-Isho. What I call the stem tone, then, would be the word final $\mathrm{H}^{\prime} \mathrm{HH}$, as the first two morae alternate $\mathrm{HH} / \mathrm{LL}$.

Regarding terminology, I use the term "morphologically complex" to cover those verb forms which have at least one morpheme which is not a root, bound subject pronoun, or class II prefix (I-).

Because word tone patterns do not vary from one root to another, I assume that roots are toneless, though they may eventually prove to contribute to the tone of a verb form. One example of consistency across roots is seen in the derivation with the Antipassive suffix in (8)-(9). Here the data are consistently high over the last TBU of the root, and Downstepped High over the two suffixal morae. Morae to the left of the last TBU of the root alternate according to the "High/Low" split.

The data in (8)-(9), along with others like them, lead to the conclusion that if there is some contribution by the root to the tone of a verb, it is the same contribution from each root. Thus the only tone classes are associated with the morphological Class I and Class II as mentioned above. It is simplest, then, to say that roots are toneless, allowing for some minimal contribution of a High tone might come from aspect or mood, as well as some contribution from the Class II prefix I-.

(8) Antipassive derivations with various roots with third person subject (initial Low)
3-(II-) root -APAS
a. ¿̀̀- dám -'íshó
'He/she/it/they...
b. è- dún -'íshó ènkèráy ... will think.'
c. è- dás -'íshó
'The child is able to cut w/o using anything else.'
d. è- gór -'íshó
... will milk by the mouth.'
e. $\quad \grave{\varepsilon}-\quad l e ́ j \quad-'$ '́shó
... will strangle.'
f. è-y- bón -'ishó
... is/are (a) liar/s.'
g. è-y- dón -'íshó
... will foretell.'
h. è-y-gér -'íshó
... pound/s.'
i. è-y-kén -'ishó
... write/s.'
j. غ̀-y- nós -'Íshó
... is/are closing.'
k. غ̀-y- நól -'Ishó
... will eat.'
1. غ̀-y- நór -'Íshó
... stir/s.'
m. غ̀-y- rrít -'íshó
... will look.'
n. غ̀-y- mán -'íshó
... is/are good at looking after cows.'
o. è- nín -'ishó
... always walk/s around.'
p. è- rìkín -'íshó
... can hear.' (... is/are awake.')
... is/are forgettable.' 
(9) First and second person forms (initial High)

1S/2- root -APAS
a. á- ány -'íshó
'I wait.'
b. á- ányít -'íshó
'I respect (people).'
c. á- dás -'íshó
'I am milking.'
d. á- gór -'ishó
'I strangle.'
e. á- nín -'ishó
'I can hear.' / 'I am awake.'
f. í gór -'ishó
'You (S) strangle.'

\section{The tonal split: morphologically complex forms}

The morphologically complex forms in this section show a split between an initial High tone for first person singular (10)-(12) and an initial Low tone for third person (again recall that second person singular (13) and inverse prefixes $1>2$ (14) and $3>2>1$ (15) pattern like first person singular). This contrast is spread over a variable number of initial TBUs: over the first mora only, as in (10); the first two morae, as in (11); or the first several, as in (12).

(10) High/Low contrast on the first mora
a. á-nín-'íshó
b. è-nín-'ishó
1S-hear-APAS
3-hear-APAS
'I can hear.'
'He/she/it/they can hear.'
c. á-y-súj-yè.
1S-II-wash-INST
'I used/will use it to wash it.'
d. è-y-súj-yè.
3-II-wash-INST
'He/she/it/they will use it to wash it.'
e. á-dún-ò
1S-cut-MID
'I am cut (in my flesh).'
f. è-dún-ò nínyè / níncè.
3-cut-MID him.NOM / them.NOM
'He/they is/are cut.'(or each other)
g. á-ytó-nìn
1S-CAUS-cut
h. è-ytó-nìn
'I will make him hear it.'
3-CAUS-cut
'He/she/it/they will make him hear it.' 
(11) High/Low contrast on the first two morae

a. á-dún-ókì

1S-cut-DAT

'I will cut for him.'

c. á-ytá-gól-'ókí

1S-CAUS-be.strong-DAT

'I will make it strong for him.'

e. á-y-dón-ókìny-yé or

á-y-dón-òkíny-yè

1S-II-beat-DAT-INST

'I will use it to pound for him.'

g. á-dún-yé

1S-cut-INST

'I will use it to cut.'

i. á-ár-ú èn-kítén àjí

1S-beat-VENT FS-cow house

'I will beat the cow into the house.' b. è-dùn-ókì

3-cut-DAT

'He/she/it/they will cut it for him.'

d. غ̇-ytà-gól-'ókí

3-CAUS-be.strong-DAT

'He/she/it/they will make it strong for him.'

f. è-y-dòn-ókìny-yé or

è-y-dòn-òkíny-yè

3-II-beat-DAT-INST

'He/she/it/they used/will use it to pound for them.'

h. è-dùn-yé

3-cut-INST

'He/she/it/they will use it to cut.'

j. $\grave{\varepsilon}-\grave{a} r-u ́ v$

3-beat-VENT

'He/she/it/they will bargain.'

(12) High/Low contrast on the first several morae (non-perfect minimal pairs unavailable)

a. á-ytó-rók-á'ká

1S-CAUS-be.black-DAT.PF

'I made it black for him.'

c. á-tá-dám-ísh'é

1S-PF-think-APAS.PF

'I thought.'

e. á-tá-gór-ókín-è

1S-PF-strangle-DAT-MID.PF

'I became angry at him.' b. ¿̀-ytj̀-ròk-á!ká

3-CAUS-be.black-DAT.PF

'He/she/it/they made it black for him.'

d. è-tà-dàm-ísh!é

3-PF-think-APAS.PF

'He/she/it/they thought.'

f. غ̀-tà-gòr-òkín-è

3-PF-strangle-DAT-MID.PF

'He/she/it/they became angry at

him/her.' 
In (10)-(12), each pair (e.g., (10a) and (10b)) is minimally different for the bound argument pronoun. The column on the left has first person singular subject forms, and the column on the right has the third person subject forms. The contrast in tone, however, may extend beyond the mora of the bound argument prefix. The tonal contrast can spread to the second mora, either the root (e.g., (11a) and (11b)) or another prefix (e.g., (7a) and (7b)). The contrast can spread as far as the third or fourth mora, covering at least a prefix and the root (e.g., (12a) and (12b)), potentially including even a suffix mora (e.g., (12e) and (12f)). The spreading of a single tone over (potentially) several TBUs is strongly implied, since the tonal split can extend over several morae, though the two forms differ only by the single mono-moraic subject morpheme.

It should be noted that (10)-(12) include a large variety of verbal affix combinations. In fact, this tonal split holds true for all non-perfect morphologically complex verb forms. (The split also holds for most perfect verb forms, c.f. (12), but a complete description of the perfect aspect is beyond the scope of this paper.) The only verb forms in the non-perfect aspect that do not show this split are certain morphologically simple forms, such as those shown in Table 4, which will be dealt with in section 4. For the remainder of this paper, the tone split in (10)-(12) between first singular and third persons will be referred to as the "High/Low" split.

As mentioned earlier, the above split is likely between third person and several argument prefixes, rather than just the first person singular. The following data show the same pattern for the bound argument prefixes other than the first person singular prefix.

(13) $2 \mathrm{~S}$

a. í-nín-ókì

2-listen-DAT

'You will agree with him.'

c. 1́-ntó-nyòr

2-CAUS-love

'You will make him love it.' b. è-nìn-ókì

3-listen-DAT

'He/she/it/they will agree with him.'

d. غ̀-ytó-nyòr

3-CAUS-love

'He/she/it/they makes him love it.'

(14) $1>2$

a. áá-tá-gór-ókín-è

1>2-PF-strangle-DAT-MID.PF

'I became angry at you(S).'

c. k-áá-ytá-gòr

DSCN-1>2-CAUS-strangle

'I will make you angry.' b. è-tà-gòr-òkín-è

3-PF-strangle-DAT-MID.PF

'He/she/it/they became angry at it.'

d. è-ytá-gòr

3-CAUS-strangle

'He/she/it/they will make him angry.' 
(15) $3>2>1$

a. kí-dún-ókì

3>2>1-cut-DAT

'You(S) will cut for me.'

c. kí-n-túk-ù

$3>2>1-I I-w a s h-V E N T$

'He/she/it/they will wash you.' b. è-dùn-ókì

3-cut-DAT

'He/she/it/they will cut it for him.'

d. è-y-túk-ù

3>2>1-II-wash-VENT

'He/she/it/they will wash it.'

The data in (13)-(15), while not conclusive, do point toward the possibility of including these other bound argument prefixes in the analyis presented in this paper.

\section{Possible analyses for the "High/Low" split}

In the preceding section, I have shown that the Il-Keekonyokie Maa bound argument pronouns evidence a "High/Low" split. The question then arises as to the specific nature of that split. Is there a High tone on the first singular prefix and a Low tone on the third person prefix in the lexicon? Or is the contrast based on more complex lexical representations (e.g., HL for $1 \mathrm{~S}$ vs. $\mathrm{H}$ for $3, \mathrm{H}$ for $1 \mathrm{~S}$ vs. $\mathrm{LH}$ for 3 , etc.) or on simpler representations (e.g., $\mathrm{H}$ for $1 \mathrm{~S}$ vs. $\varnothing$ for 3 )? In this section, I outline three analyses that might be proposed to account for the contrast between first person singular and third person argument forms. These three analyses consider the contrast to be between 1) two fully specified lexical tones on the prefixes; 2) High tone on the first singular prefix vs. the third person tone underspecified and supplied by rule; and 3) Low tone on the third person prefix vs. the first person singular tone underspecified. The following sections lay out these possibilities, and explore their implications, showing the third to be the superior analysis.

Because the "High/Low" split is neutralized in all short forms (section 5), and because I have very few morphologically simple long forms, the following sections will show derivations with morphologically complex forms, though with only one derivational affix. The lexical entries given in the first step of the derivations (e.g., (17a) and (e)) show lexical forms before the application of certain phonological rules, such as vowel harmony (which includes /a/ $\rightarrow / \mathrm{o} /$ allomorphy for +ATR environments) and word-final affixal consonant loss [Levergood 1987, Wallace 1981, and Wallace-Gadsen 1983].

3.1. Full Specification Analysis. The full specification analysis assumes that the underlying representations for both first person singular and third person bear a tone which is fully specified in the lexical form of the prefix, as in (16). This would lead to a derivation like (17), which compares (11a) with (11b).

One variation of this analysis has the prefix tone associating at a later stage than suffix tones, and in a left to right manner, followed by left to right spreading. This would differ from (17), above, in that for $\mathrm{b}$ and $\mathrm{f}$, the prefixal tone would associate to the leftmost TBU (i.e., the prefix) then spread rightward to the root in $\mathrm{c}$ and $\mathrm{g}$. 
(19) Derivations with instrumental suffix: ' $\mathrm{I} / \mathrm{He}$ will use it to cut.'
a. $\mathrm{H}$
$\mathrm{H}$
e. L
$\mathrm{H}$
Lexical entries
a- dun -ye(k)
$1 \mathrm{~S}$ cut INST
$\varepsilon$ - dun -ye(k)
3 cut INST
b.
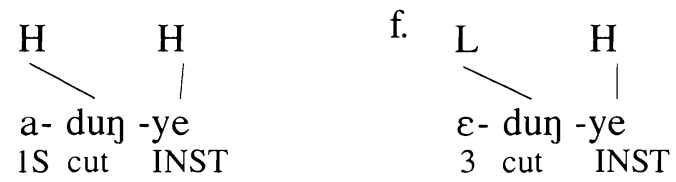
$\begin{array}{ccc}\text { c. } & \mathrm{H} \\ \vdots & \mid \\ \text { a- dup } & -\mathrm{ye} \\ 1 \mathrm{~S} \text { cut } & \text { INST } \\ * & \downarrow & \ldots \ldots . . .\end{array}$

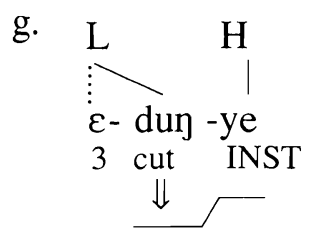
Spreading (R to $\mathrm{L}$ )
d. *á-dún-'yé
'I will use it to cut.'
h. è-dùn-yé
Surface realization
'He/she/it/they will use it to cut.'

bound argument pronoun, as well as word final, causing downstep. However, the correct first person singular form, given in $(11 \mathrm{~g})$, does not have downstep but, rather, is High and level in tone.

The ventive suffix, as in (11i) and (11j), would require an analysis tonally identical to that given in (19) for the instrumental. Both morphemes have a single High tone in the third person forms, and both have a high and level pitch, without downstep, in the first person forms. If the first person singular prefix adds any lexical tone to the word tone pattern, then the high and level pitch on the first person singular form would need to be seen as at least as complex tonally as the lowhigh pattern of the third person form. Given that the first person forms in (11g) and (11i) have fewer surface tonal contrasts than the third person forms in (11h) and $(11 \mathrm{j})$, it is perhaps simpler to admit the lack of lexical tone on the first person singular bound argument pronoun. Given these instrumental and ventive data, the full specification analysis cannot work. The only way to make such an analysis work would require a rule merging the adjacent High tones in phrase-final position, but such a rule is not otherwise needed and would undermine the understanding of downstep in Il-Keekonyokie Maa presented in Rasmussen \& Payne [2001].

3.2. Third person underspecification with default Low. A second, "third person underspecification", analysis could be proposed for Il-Keekonyokie Maa. Such an analysis would assume lexical entries for Il-Keekonyokie Maa with the third person bound argument pronoun $(\varepsilon-)$ lexically unspecified for tone and the 
Low tone supplied by a default tone rule. This thesis has been put forth for particular Bantu languages, e.g., Chichewa [Meyers 1998] and Haya [Hyman \& Byarushengo 1984] inter alia, and even for Bantu in general [Stevick 1969], however speculative that claim may be. A default tone has phonological validity, but is added by rule, rather than being lexically specified [Snider 1999, Clark 1989, inter alia]. The lexical representations of the prefixes would be as in (20), leading to a derivation something like either (21) or (22). As the derivations in (21)-(22) show, the need for both a default low assignment rule and spreading causes a conflict. The derivation in (21) assumes ordering of spreading before default tone association.

(20) Lexical entries for bound argument prefixes

(Low underspecification analysis)

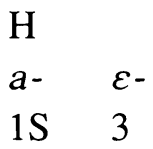

(21) Low underspecification analysis of 'I/He will cut for him.'

(spreading before default Low tone assignment)
a. $\mathrm{H}$
H L
e.
H L
Lexical entries
a- duj -aki(n)
1S cut DAT
e- dun -aki(n)
3 cut DAT

b.

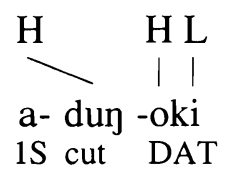

f.

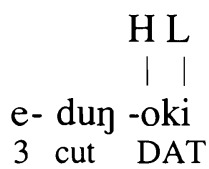

Association ( $\mathrm{R}$ to $\mathrm{L}$ )

c.

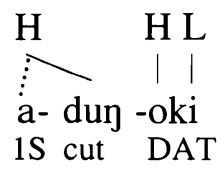

g.

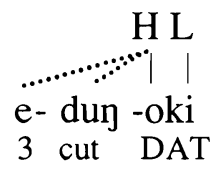

Spreading ( $\mathrm{R}$ to $\mathrm{L}$ )

d. N.A.-no empty TBUs á-dún-ókì

'I will cut for him.'

h. N.A.-no empty TBUs Default assignment *é-dún-ókì Surface realization 'He/she/it/they will cut for him.'

This derivation gives the correct form for the first person, but not for the third person form, since spreading occurs before the default Low tone is assigned. The third person form can be derived correctly by reversing the order of default tone 
(22) Third person underspecification analysis of 'I/He will cut for him.' (default assignment before spreading)
a. $\mathrm{H} \quad \mathrm{H} \mathrm{L}$
e.
$\mathrm{HL}$
Lexical entries
a- duy -aki(n)
e- dun -aki(n)
1S cut DAT
3 cut DAT
b.

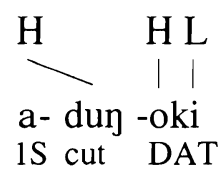
f.

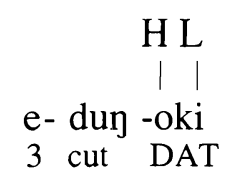
$\begin{array}{cccc}\text { c. } & \mathrm{L} & \mathrm{H} & \mathrm{H} \mathrm{L} \\ \vdots & \text { I } & \mid \\ \text { a- dup } & \text {-oki } \\ \text { 1S cut } & \text { DAT }\end{array}$
$\begin{array}{cccc}\text { g. } & \text { L } & \text { L } & \text { H L } \\ \vdots & \vdots & \mid & \mid \\ \text { e- } & \text { dup } & \text {-oki } \\ 3 & \text { cut } & \text { DAT }\end{array}$
Association ( $\mathrm{R}$ to $\mathrm{L}$ )
d. N.A.-no empty
TBUs
h. N.A.-no empty TBUs Spreading (R to L)
*à-dún-ókì
è-dùn-ókì
Surface realization
'I will cut for him.'
'He/she/it/they will cut for him.'

assignment and spreading, giving the derivation in (22).

With this ordering the third person form is correct, but the first person form is not, because an empty TBU was available for a default tone to be assigned in (22c). This default tone assignment then doesn't allow the spreading of the High onto the leftmost TBU in (22d), leaving the initial TBU incorrectly Low. The problem for the default Low analysis is that the spreading rule and the default assignment rule use the same input (an unassociated TBU), but the two rules need to operate in different cases. For the first person forms, the correct surface form can only be achieved by ordering spreading first, leaving no unassociated TBUs for default tone assignment. The third person forms, however, would need the opposite ordering, with the default Low tone assigned before the suffix tone spread onto the empty TBUs.

We now turn to a third analysis, which also uses underspecification, but assumes no default tone assignment.

3.3. First person singular underspecification (with spreading). A third possibile analysis would have the tone of the first person singular prefix unspecified, assuming lexical representations as in (23). Such an analysis was has been proposed for Ciruri (Bantu) verb roots [Botne 1990], where a High/low contrast, or a High/unspecified contrast was not sufficient to account for the data. 
(23) Lexical entries for bound argument prefixes

(High underspecification analysis)

$$
\begin{array}{ll} 
& \text { L } \\
a- & \varepsilon- \\
1 S & 3
\end{array}
$$

Under this analysis, the High tone in the first person singular forms (10)-(12) doesn't come from the prefix, but is spread from the stem. For third person forms, the Low tone from the prefix associates after the stem tones (24f), and spreads to empty TBU's on its left (because it is the last tone on the left- $(24 \mathrm{~g})$ ). The association of the Low tone from the third person prefix blocks the spreading from any suffixal Highs, which associated further to the right. For the first person singular forms, there is no prefix tone, so the suffix High tone is the leftmost, which then spreads to the empty TBU's on its left, as shown in (24c).

(24) High Underspecification analysis of 'I/He will cut for him.'
a.
H L
e. L
H L
Lexical entries
a- dun -aki(n)
e- dun -aki(n)
1S cut DAT
3 cut DAT
b.

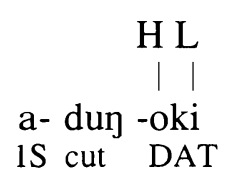
f. $\underbrace{\mathrm{L}}_{\text {e- dup -oki }} \underset{\substack{\mathrm{H} \\ \mathrm{L}}}{\mathrm{D}}$
3 cut DAT
c.

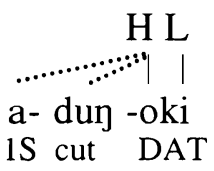
$\begin{array}{lll}\text { g. } & \text { L } & \text { H L } \\ \vdots & \mid & \mid \\ \text { e- dup } & \text {-oki } \\ 3 & \text { cut } & \text { DAT }\end{array}$
Association ( $\mathrm{R}$ to $\mathrm{L}$ )
d. á-dún-ókì
h. è̀-dùn-ókì
Surface realization
'I will cut for him.'
'He/she/it/they will cut for him.'

According to this analysis, the suffixal High spreads to the beginning of the word in the first person singular form, while the association of the prefixal Low tone in (24f) blocks spreading of the suffixal High tone in the third person form. It produces the correct forms for both first person singular and third person, and doesn't cause conflicts with other aspects of the analysis, unlike the full specification analysis (section 3.1).

Given the data in (10)-(12) then, the best analysis for the alternation between first person singular and third person forms is underspecification of the first person 
singular prefix, as exemplified in this section. The initial High tone seen on the first person argument prefix is spread from the suffix leftward to the beginning of the word.

\section{The exception: morphologically simple forms}

The preceeding sections have shown data which evidence a tonal split between IlKeekonyokie Maa bound argument pronouns. In this section, I present data which evidence a neutralization of that split, beginning with morphologically simple forms.

While Il-Keekonyokie Maa verbs may take a large amount of morphology, as shown, for example, in (10)-(12), they are minimally composed of a root preceded by a bound argument pronoun, which may compose an entire clause, as in (25)(27). I use the term "morphologically simple" to refer to those inflected forms with only an argument pronoun and an unanalyzable stem, including the Class II prefix $i$ - for Class II stems.

"High and level" tone patterns (Class I roots)
(25) a. á-ló
(26) a. í-ló
$(27)$
a. é-ló
1S-go
2-go
'I will go.'
'You (S) will go.'
3-go
'He/she/it/they will go.'
b. á-nyór
b. Í-nyór
2-love
b. ع́-nyór
1S-love
'You (S) love it.'
3-love
'I love (him).'
c. í-bík
'He/she/it/they loves.'
c. á-bík
1S-stay
'I'll stay here.'
2-stay
'Will you (S) stay
here?'
c. é-bík
3-stay
'He/she/it/they will stay.'

Unlike the data in sections 2 and 3, i.e., (10)-(15), the tone in (25)-(27) is the same for all listed word forms, regardless of which bound argument pronoun is prefixed to the root. This "High and level" tone pattern is seen with these bound argument pronouns on all morphologically simple Class I verb forms, except for nine forms to be given and addressed in section 5.1. The same tone patterns across the forms in (25)-(27) might imply that the bound arguments are tonally identical (though the data in section 2 clearly contradict it).

Splitless Analysis

The first person singular, second person, and third person bound argument prefixes bear an identical (probably High) lexical tone.

This analysis would also account for the morphologically simple class II forms in (29)-(31), where the tone pattern is again the same for all word forms given, 
regardless of bound argument pronoun. Here, however, the tone pattern is HighLow, as class II stems are involved, rather than the "High and level" tone pattern for short morphologically simple verbs with Class I stems.

"High-Low" tone patterns (Class II roots) 8
(29)
a. á-y-kèn
(30) a. 1-n-kèn
1S-II-shut
2-II-shut
'I will shut it.'
'You (S) will shut it.'

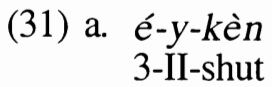
'He/she/it/they will shut
it.'
b. á-y-sùj
1S-II-wash
'I will wash it.'
b. Í- $\varnothing-s u ̀ j ~$
2-II-wash
'You (S) will wash
it.'
c. $k$-á-y-bèl
DSCN1S-II-rock
'I will rock from
side to side.'
b. $\varepsilon-y-s u ̀ j$
3-II-wash
'He/she/it/they will wash it.'

\section{c. é-y-bèl \\ 3-II-rock}
'He/she/it/they will rock from side to side.'

The data in (25)-(31), by itself, could be accounted for with the Splitless Analysis, along with the assumption that Class II stems, either in the Class II prefix or the root, bear a lexical Low tone. The data in (32)-(35) might suggest that this analysis works regardless of root shape, $\mathrm{CVC}, \mathrm{CV}$, or VC.

As mentioned previously, the data in (25)-(27) vs (29)-(31) exhibit a tonal distinction between Class I and Class II verb roots in the morphologically simple derivation. So, the Splitless Analysis (28) could account for the morphologically simple

(32)
a. á-ból
'I hold/twist the cow's mouth.'
b. á-tón
'I will stay/sit here'
c. á-ár èn-kítén
'I will beat the cow.'
d. á-yá ìn-kírí
'I will take the meat.'

3 subjects w/ Class I roots
a. É-ból
'He/she/it/they will open the cow's mouth.'
b. É-tón
'He/she/it/they will sit.'
c. É-ár
'He/she/it/they beats/kills it.'
d. é-yá èn-gárí
'The car will take it.'

8 The second person forms in (30a) and (30b) show the regular phonological rules $/ \mathrm{i} / \rightarrow / \mathrm{n} / /$ $/ \mathrm{i} /+\ldots$ (dissimilating bimorphemic high front vowels) and $/ \mathrm{n} / \rightarrow \emptyset / \ldots / \mathrm{s} /$ (dropping a nasal before a sibilant). 
1S subjects w/ Class II roots
a. á-y-gìs
'I will jump.'
b. á-y-kàsh
'I am better than him.'

\section{3 subjects w/ Class II roots}

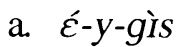
'He/she/it/they will jump.'
b. É-y-kàsh
'He/she/it/they is/are better than him.'

forms in (25)-(35). But, with addition of any other morphology on a verb, the analysis fails. All of the morphological combinations given in section 2 showed a tonal contrast between first person singular and third person. Because the pairs of verbs that are minimally different for subject are also minimally different for tone, a hypothesis that first singular, second person, and third person are tonally identical is untenable.

Given then, that the Splitless Analysis cannot account for the tonal split observed in section 2 , the next section will resolve these two bodies of data into a single analysis by showing how the split observed in section 2 is neutralized in the data in (25)-(35).

\section{Resolving the split and neutralized data}

In this section, I propose that the "High/Low" tone split from section 2 is a lexical tonal contrast, according to the analysis in section 3 . That lexical contrast is neutralized in a specific environment, as found in both the "High and level" Class I and "High-Low" Class II tone patterns of (25)-(35).

It has already been stated that the forms in (25)-(35) are morphologically simpler than those in (10)-(12); it should be noted that the forms in (25)-(35) are also words with only two morae. Either length or morphological complexity might prove useful in understanding a morphophonemically conditioned split. But I will show that the number of morae, rather than morphological simplicity, conditions the difference between the forms with the split, i.e., (10)-(12), and those without it, i.e., (25)-(35).

For reasons that will become clear, I address Class I and Class II roots independently. Section 5.1 considers a rule to account for the neutralization seen with Class I roots, making the initial assumption of length as the conditioning environment. In section 5.1.1, I give nine roots that are lexical exceptions to that rule, which also show the "High/Low" split. In section 5.1.2, I present further data which show that length, and not morphological simplicity, is the conditioning environment for neutralization. I treat the neutralization in verbs with Class II roots in section 5.2.

5.1. Class I roots. One could hypothesize that the first person singular and second person forms in (25)-(27) work the same as the first person singular forms in (10)(12), with the first person singular prefix associated to a stem High in all cases. The simple third person forms in (27a-c) could then be accounted for by assuming the third person prefix is lexically Low, which would account for the third person 
forms in (10)-(12), with the following delinking and spreading rule (36), shown with the data from (27)a.

(36) Two-mora High Spread (TMHS) ${ }^{9}$

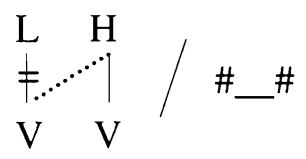

ex. /èló/ $\rightarrow$ [éló] 'He will go.'

This rule claims that a High tone delinks a Low tone on a preceding vowel and is conditioned to apply when the only morae in the word are those two morae that are involved in the rule. Possible motivation for the delinking of the Low tone comes from the fact that rising tones are prohibited over a single mora in all environments. Thus, if spreading gave rise to the form in (37), the result would be what is seen in (36).

(37) Spreading, creating L-H rise over initial TBU

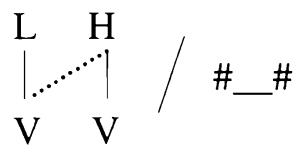

ex. /èló/ $\rightarrow$ *[`éló] 'He will go.'

It could be said that TMHS is essentially the same spreading seen in sections 2 and 3, with a negative structure condition removing the rising tone. It should be noted, however, that this spreading is distinct from the spreading which causes the alternations seen in sections 2 and 3. In TMHS, a tone is spreading onto a TBU which is already associated to a tone, rather than to an empty TBU. TMHS is also bound by a particular phonological environment, as I will show in the following sections. If High tones regularly spread onto TBUs with Low tones, we would expect the data given in section 2 to include either spread High tones preceeded by Low tones (if the spreading is non-iterative) or no Low tones at all before High

${ }^{9}$ This will probably ultimately be generalized to the following:

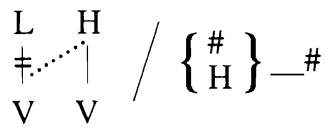

ex. /èdùnákìní/ $\rightarrow$ [èdùnók'iníi] 'He will be cut for.' 
tones (if the spreading was iterative). We see neither of these, giving evidence that the spreading in TMHS is unique to this environment.

Given these assumptions, then, TMHS (36) accounts for the neutralization of the split on the verb forms in (25)-(27) according to the derivations in (38). The tone associates and spreads normally (i.e., right to left) onto the first person argument prefix, which is lexically unspecified for tone. In the third person form, on the other hand, the stem High tone delinks the prefixal Low tone, giving a "high and level" tone pattern. The underlying forms are given according to the assumptions laid out in section 3.3, with the High tone coming from aspect/mood.

(38) Derivation of TMHS neutralization of tone patterns ('I/He will go.')

a. $\mathrm{H}$

a- lo

1S go

b.

$\underbrace{H}_{\text {a- lo }}$
1S go

c.

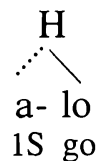

d. - [NA]

e.

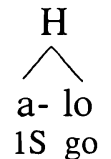

á-ló

'I will go.' f. $\mathrm{L} \mathrm{H}$

$\varepsilon-\operatorname{lo}(\mathrm{t})$

3 go

g.

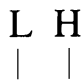

e- lo

3 go

h. - [no empty TBUs] Spreading (R to L)

Association ( $\mathrm{R}$ to $\mathrm{L}$ )

\section{TMHS}

$$
\neq . \cdot \cdot 1
$$

e- 10

3 go

$\mathrm{j}$.

Surface realization

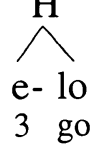

é-ló

'He/she/it/they will go.'

5.1.1. Lexical exceptions to TMHS. TMHS (36) predicts that there will not be a Low-High tone pattern on any 2 -mora verb. It should be noted, however, that I 
have found a few verbs that do not undergo this rule, and are pronounced lowhigh over only two morae. I list them exhaustively in (39).

With any additional morphology, the roots in these verbs behave tonally like other Il-Keekonyokie Maa verbs, for example, (11c) and (11d) for gol (39c) with the Class I causative (CAUS) and dative (DAT), repeated in (40) and (41).

(39) Lexical exceptions to Two-mora High Spread

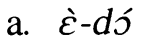
'The rock is red.'
b. è-dwá
'He/she/it/they is/are bitter.'
c. è-gól j̀-sòít
'The stone is hard.'
d. è-ykó
'He/she/it/they will do that.'
e. $\grave{\varepsilon}-y r o ́$
'He/she/it/they will speak.'
f. è̀-yshú
'He/she/it/they is/are alive.'
g. è-ó j̀l-máysùrí láy
'My banana has already ripened / is ready.'
h. è-pír ìn-tárè ínònó
'Your sheep are fat.'
i. غ̇-shá
'It will rain.'/ 'It rains.'

(40) á-ytá-gól-'ókí

1S-CAUS-be.strong-DAT

'I will make it strong for him.'

(41) غ̀-ytà-gól-'ókí

3-CAUS-be.strong-DAT

'He/she/it/they will make it strong for him.'

If the lexical representations of the roots in (39) bore different lexical tone from other roots, one would expect to see the impact of that tonal contrast throughout the derivations involving that root, or at least in several derivations. These roots, however, are only exceptions in the simplest form, given in (39). This lack of further exceptionality suggests that they are marked in the lexicon to disallow Two-mora High Spread (36), rather than being tonally distinct from other roots in the lexicon.

Further, the first person singular inflections for the verbs in (39) are High and level in (42), like the simple first person singular forms with all other roots-compare, for example, (25)a-(25)c.

(42) First person singular forms
a. á-gól
'I am strong.'
b. á-yshú
'I am alive.'
c. á-pír
'I am fat.' 
This means that the tonal distinction for these roots only affects the third person inflection, as the verbs in the first person singular inflection are tonally identical to verbs with other roots. Also, the forms in (39) and (42) show the same "High/ Low" tonal split seen in (10)-(12).

The "exceptions" to Two-mora High Spread in (39) are thus further evidence for a regular "High/Low" split between first person singular and third person. These roots, being exceptions to the neutralization in (36), have the same argument prefix split as do the forms in (10)-(12). In other words, the forms in (39) are exceptions to Two-mora High Spread (36), but fall into the regular "High/Low" pattern, as in (10)-(12). This confirms that there really is just one pattern of High/ Low split for $1 \mathrm{~S}$ vs. 3 subjects, and that there is a specific rule (36), with a specific phonological context (two morae), with specific lexical exceptions (39), that accounts for all exceptions to that split.

5.1.2. Longer roots. TMHS (36) claims that length alone, and not morphological simplicity, is the environment that conditions the neutralization of argument prefixes in verbs with Class I stems. This is difficult to test with the available data, since most Il-Keekonyokie Maa verb roots in the available data have a (I) CVC structure, and few are longer-so morphological simplicity and short length generally go together. To conclusively prove the environment for (36), we need (a) verbs which are longer than two morae, yet morphologically simple, as well as (b) verbs that are only two morae, yet morphologically complex. If we find both (a) and (b), we would expect only one of them to neutralize the split, and which one does would indicate the correct environment for (36).

(43) Longer morphologically simple Class I forms.
a. á-ádó
1S-be.tall
b. $\grave{\varepsilon}$-àdó
'I am tall.'
3-be.tall
'He/she/it/they is/are tall.'
c. á-dámú
1S-remember
d. è̀-dàmú
'I remember.'
3-remember
'He/she/they remember(s).'
e. á-lálá
f. è-làlá
1S-be.wide
'I am wide.'
3-be.wide
'It is wide.'
g. á-múrát
1S-circumcise
'I will circumcise (him),'

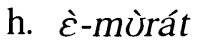
3-circumcise
'He/she/it/they will circumcise him.'
i. á-rrúgúm
j. è-rrùgúm
1S-vomit
'I will make him vomit.'
3-vomit
'He/she/it/they will make him vomit.' 
While there are not many (b) verbs (short but complex), there are a few (a) verbs which are longer but not apparently more complex, as shown in (43). Those familiar with Nilotic morphology may question the morphological simplicity of some of these pairs, such as (c-d), which may historically have the ventive $-v$, and (e-f), which looks like it has the middle form, though it has a different tone pattern from the normal middle form (which is High-Low on the final two morae-as in $(10 \mathrm{e}-\mathrm{f}))$. At least $(\mathrm{a}-\mathrm{b}),(\mathrm{g}-\mathrm{h})$, and $(\mathrm{i}-\mathrm{j})$, however, have no apparent synchronic or diachronic analysis.

As (36) predicts, the "High and level" pattern in (25)-(27) breaks down for longer Class I roots, as seen in (b), (d), (f), (h), and (j). The tone pattern for longer simple third person forms is Low initially, then High on the final mora, while the first person forms are High and level. In fact, these longer roots show the same "High/Low" split found in (10)-(12), only here on morphologically simple roots. Since these roots have no evidence of morphological complexity and do not undergo neutralization, it cannot be maintained that morphological simplicity is the conditioning factor for the neutralization in (25)-(27).

In sum, the fact that the data in (43) show the same "High/Low" split as in (10)-(12) indicates that it is not morphological simplicity, but length, which is the environment that conditions the "High and level" neutralization in (25)-(27), and that there is, again, a single High/Low split pattern.

To establish length as the conditioning factor in (36) the only question left concerns the presence of (b) verbs: two-mora morphologically complex forms. Do these forms show neutralization of the split? The following data is at least diachronically morphologically complex, though the synchronic complexity is uncertain. But it is the only minimal pair of verbs avaliable with both no more than two morae and also (potentially) morphologically complex.

(44) a. á-bá-w

1S-reach-VENT

'I will arrive.' b. É-bá-w

3-reach-VENT

'He/she/it/they will arrive.'

The data in (44) show the neutralization of the "High/Low" split, unlike the ventive data in $(11 \mathrm{i}-\mathrm{j})$, which has a Low-High contrast in the third person form. This neutralization of the expected contrast may provide evidence that morphological simplicity does not condition the neutralization of that split. It is not clear, however, whether what is clearly the ventive morpheme diachronically is synchronically distinct from the root, or if they have become lexicalized into a single morpheme. Unfortunately other short but complex forms are unavaliable at this time.

The data in (43), then, show that with more than two morae, morphologically simple verbs with Class I stems do not show neutralization, but rather the "High/ Low" split. It is not entirely clear yet, but there is some evidence in (44) that morphological simplicity is not required for neutralization of the "High/Low" split. So, verbs with only two morae exibit neutralization of the "High/Low" split, with or without morphological simplicity, and verbs with more than two morae do not. 
Thus, length, and not morphological complexity, is established as the conditioning factor for TMHS (36).

5.2. Class II roots. Section 5.1 showed that the "splitless" tone pattern for Class I roots in (25)-(27) can be seen as a neutralization of the "High/Low" split, conditioned by length. Similarly, the "High-Low" simple Class II pattern in (29)-(31) can be seen as a neutralization conditioned by length, though in a slightly different manner. Rather than a lexical phonological rule that eliminates the split, this neutralization would be the result of the association of one tone to each TBU.

Looking at the stem tones (i.e., those that don't alternate for argument prefixrecall section 1.3) in the data so far presented, one notices a fairly limited set of patterns. Depending on the derivation of the stem, the stem has a certain number of tones: either one (e.g., (11g) vs. (11h)), two (e.g., (10e) vs. (10f)), or three (e.g., (11c) vs. (11d)). These tones associate right to left, filling all TBUs, including the ultimate, penultimate, and antepenultimate, respectively. Assuming stem tones, being on the right, associate before argument tones, which are on the left, the number of stem tones will determine where the argument tones associate.

According to this way of looking at the data, the simple Class I roots (section 5.1) have one stem tone, so the High tone spreads from the ultimate mora in the first person singular forms, leftward to the beginning of the word. The third person Low tone, and thus the split in argument prefix tone, is realized on the penultimate mora, as in (43). The Penultimate mora is also the first mora on two mora words (39), though this is neutralized in most forms by TMHS (36), as in (25)-(27).

Class II roots, on the other hand, have two stem tones, so these tones associate with the ultimate and penultimate TBUs (29)-(31). Because the stem tones com-

(45) Analysis of simple Class II neutralization
a. $\quad \mathrm{H} \mathrm{L}$
e. L H L
Lexical entries
a-ygis
$\varepsilon$-ygis
1S-jump
3-jump
b. $\quad \mathrm{H} \mathrm{L}$
a-ygis
1S-jump
c. - [no empty TBUs]
d. áygìs
'I will jump.'
f. $\mathrm{L} \stackrel{\mathrm{H}}{\mathrm{L}}$
$\varepsilon$-ygis
3-jump
g. - - [no empty TBUs] Spreading (R to L)
h. éygìs
Surface form
Association ( $\mathrm{R}$ to $\mathrm{L})$
'He/she/it/they will jump.' 
pletely fill the TBUs, the third person argument prefix Low tone cannot associate (and is presumably deleted), so the "High/Low" split does not surface. The derivations are given in (45). With longer words, however, the antepenultimate tone associates to the antepenul-timate mora, so the "High/Low" split is again realized on the surface, as in (46).

(46) Simple Class II verb forms with three morae
a. á-y-nínìn
1S-II-listen.RED
b. è-y-nínìn
'I will listen.'
3-II-listen.RED
'He/she/it/they is/are listening.'
c. á-y-rówùà
1S-II-be.hot
d. غ̀-y-rówùà
'I am hot.'
3-II-be.hot
'He/she/it/they is/are hot.'
e. á-y-térrè
1S-II-faint
f. $\grave{\varepsilon}-y$-térrè
'I will faint.'
3-II-faint
'He/she/it/they will faint.'
g. á-y-rúrà
1S-II-sleep
h. غ̀-y-rúrà
'I am asleep.'
3-II-sleep
'He/she/it/they is/are asleep.'

The additional TBU allows the prefix tone to associate, allowing the "High/Low" split to surface, as in (47). This analysis neutralizes the "High/Low" split for verb forms with class II roots that have just two morae, but accounts for the split occurring on longer words.

The analysis presented in this section for verbs with Class II stems accounts for the neutralization of the "High/Low" split in an entirely different way than the Two-mora High Spread (36), which accounted for the neutralization in verbs with Class I stems (25)-(27). Because the analyses for verbs with each of these two classes of stems differ, we might expect the neutralizations to have different properties. And this is what we find: unlike Two-mora High Spread (36), which is a phonological rule with several lexical exceptions, i.e., the roots in (39), the analysis in (47) has no room for lexical exceptions, as there is no rule which might be susceptible to lexical specification. The neutralization analysis in (47) is merely a matter of the relationship of the number of tones to the number of TBUs in a given verb. This prediction of an exceptionless split is met by the lack of exceptions (so far) to the simple class II High-Low tone pattern over two morae verbs, regardless of root. 10

10 The roots in (39d) and (39e) above, however, may prove to be Class II, in which case they would seem exceptional. However, I don't have data with these roots in other derivations, so I am not sure if they are Class II stems. There is data indicating that (39f) is not a class II root. It is an 
(47) Analysis of simple Class II non-neutralization
a. $\quad \mathrm{HL}$
d. L H L
Lexical entries
a-yrura
$\varepsilon$-yrura
1S-sleep
3-sleep
b.

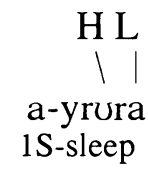
e. $\quad \underset{\mid}{\mathrm{L}} \quad \mathrm{HL}$
$\varepsilon$-yrura
3-sleep
Association ( $\mathrm{R}$ to $\mathrm{L}$ )
c.

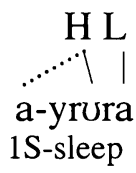
f. - [no empty TBUs] Spreading (R to L)
d. áyrứà
i. ̇̀rứrà
Surface form
'I will sleep.'
'He/she/it/they will sleep.'

\section{Conclusion}

The first person singular underspecification analysis may or may not match analyses proposed for other Nilotic person marking systems. The only published analysis including a bound-pronominal split, for any Nilotic language, is Dimmendaal's [1983] analysis of Turkana. His analysis for Turkana seems essentially the same as my Full Specification Analysis as given in 3.1 above.11 While Full Specification may work for Turkana (and perhaps for other Nilotic languages), claiming a lexically specified High tone for the first person singular bound argument pronoun is not ideal for a synchronic analysis of Il-Keekonyokie Maa.

The analysis presented in this paper claims that every tone after (and including) the first High tone on the third person forms is due to the stem, indicating that the same tones are also due to the stem in the first person singular forms. Consider the first pronunciation given for (11e) and (11f), presented here in (48). The stem tones are viewed as the same, since the pair of words is minimally different for subject,

interesting coincidence that these three roots have ${ }_{\mathrm{I}} \mathrm{CV}$ stem structure, unlike the $\mathrm{ICVC}$ forms in (29)-(31) and (46).

11 While a fully specified pronominal tone split is given in Dimmendaal [1983], it is clearly not a focal point of the 1983 work, and it is not clear whether underspecification of any of those pronouns was considered. Thus, it may be of little consequence if Maasai requires a different analysis. 
and identical in stem. The initial High tone in the first person singular form, then, is contiguous with a High tone from the stem. One could claim that there are two distinct High tones in the first person singular forms, which are not distinguished on the surface, but it would be simpler just to say that there are no more High tones in the first person singular forms than in the third person forms, with adjacent high morae considered to be associated to the same High tone (49), in accordance with the OCP.

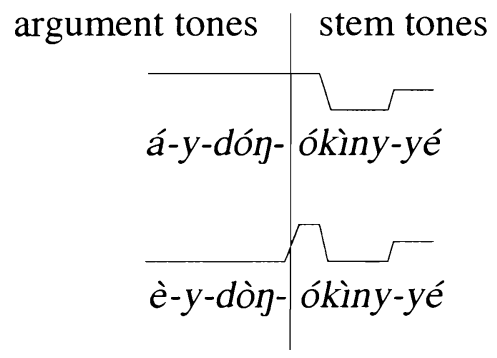

1S-II-beat-DAT-INST

'I will use it to pound for him.'

3-II-beat-DAT-INST

'He/she/it/they will use it to pound for him.'

(49)

$$
\text { á-y-dón-ókìny-yé }=\text { two high tones }
$$

Thus, if one were to claim that there is a lexical High tone on the first person singular prefix, one would also need to claim that there is merger of adjacent Highs in each and every verb with an initial High tone. This would be the case because the initial surface tone is not distinguished phonetically from the stem High tone; the word tone is high and level from the beginning of the word to the mora which is the leftmost High tone in the third person form (i.e., the first stem tone). Put differently, the domain of morae associated to the initial High tone in the first person singular forms always includes one mora (the rightmost-before the verticle line in (50)) which is also High in the same derivation with a third person subject, as throughout (10)-(12). 


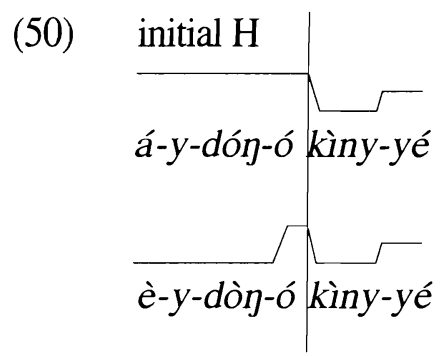

In other words, the first and third person forms share at least one High-toned mora, which is contiguous with the word initial High tone in the first person singular forms of (10)-(12). If one were to claim that the tone to the left of the vertical line in (50) were due to the argument prefix for first person singular, one would also need to say that the third person tone is Low-High-unless there is some reason that the high tone on -ókì should come from the argument prefix in the first person singular form, but from the stem in the third person form.

Alternatively, one might defend full specification by saying that the stems exibit tonal allomorphy for each of the argument prefixes, with one fewer High tone after first person singular forms, though this gains nothing over the analysis in section 3.3 , but only adds complexity.

Thus, there is no clear empirical evidence that the High tone on first person singular, second person, etc. forms comes from those prefixes, as opposed to being spread from the stem. Requiring full specification of tone also increases the complexity of the analysis unnecessarily and without any apparent benefit. Beyond considerations of economy and unnecessary complexity, when the instrumental and ventive data discussed in section 3.1 are considered, it is clear that a lexically independent tone on the first person singular prefix is untenable.

Finally, we have seen that for both Class I and Class II roots, the tonal alternation between first and third person is neutralized over only two morae. I propose that this neutralization occurs, on the one hand, by a spreading rule (36) that delinks the third person Low tone in most two-mora words with Class I roots, and, on the other hand, by having fewer TBUs in the word than tones in the word tonal melody for Class II roots, as in (47).

Given this analysis, then, we can say that there is a lexical split between first and third persons. Surface "High" prefixes (1S, 2, etc.) are lexically unmarked for tone and the "Low" prefix (3) is lexically marked Low. Lexically toneless morae then receive tone by spreading from the stem on the right. All deviations from this split have been accounted for in Section 5.

While this paper has focused on the contrast between the first person singular an the third person bound argument prefixes, it is likely that the the first person singular prefix is tonally identical to the second person prefix (i.e., I-lám from Table 4), as well as to the first person singular acting on second person singular prefix (i.e., áá-lám from Table 4), and to the third person acting on second person singular or second person acting on first person singular prefix (i.e., kí-lám from Table 4). 
This analysis now sets the stage for a comprehensive analysis of the whole verb argument prefix system of Il-Keekonyokie Maa, allowing the interactions between the rest of the morphology on verbs to be studied.

\section{REFERENCES}

Bavin, Edith L. 1980. "Lango: Some morphological changes in verb paradigm." In Thilo C. Schadeberg and M. Lionel Bender (eds.), Nilo-Saharan: Proceedings of the First Nilo-Saharan Linguistics Colloquium, Leiden, September 8-10, 1980. Foris: Dordrecht. Pp. 89-100.

Clark, Mary M. 1989. “OCP Effects in Zulu.” Linguistic Analysis 19: 59-76.

Creider, Chet A. and Jane Tapsubei Creider. 1989. A Grammar of Nandi. (NiloSaharan: Linguistic Analyses and Documentation vol. 4) Hamburg: Helmut Buske.

Dimmendaal, Gerrit. 1983. The Turkana language. Foris: Dordrecht.

Greenberg, Joseph 1963. The Languages of Africa. Bloomington and The Hague: Indiana University Press.

Grimes, Barbara F. 2000. Ethnologue: Languages of the world. (13 ${ }^{\text {th }}$ edition, internet version). Revised 7-Dec-2000.

Hyman, Larry M. and Ernest Rugwa Byarushengo. 1984. "A model of Haya Tonology." In G. N. Clements and J. Goldsmith (eds.), Autosegmental Studies in Bantu Tone. Foris: Dordrecht. Pp. 54-103.

König, Christa. 1993. Aspekt im Maa. Köln: Institut für Afrikanistik, Universität zu Köln.

Levergood, Barbara. 1990. "The syllable in Maasai.” Ms, University of California, San Diego.

Levergood Barbara. 1987. "Topics in Arusa phonology and morphology." PhD. Dissertation, University of Texas at Austin.

Meyers, Scott. 1998. "Surface underspecification of tone in Chichewa." Phonology 15:367-391. 
Payne, Doris. 1995. "Review of Christa König: Aspekt im Maa." Journal of African Languages and Linguistics 16:191-194.

Payne, Doris, Mitsuyo Hamaya, and Peter Jacobs. 1994. "Active, inverse and passive in Maasai." In T. Givón (ed.), Voice and Inversion (Typological Studies in Language 28), Amsterdam and Philadelphia: John Benjamins. Pp. 283-315.

Rasmussen, Kent and Doris Payne. 2001. "The discourse marker $k$ - and High tone processes in Il-Keekonyokie Maa." Ms., University of Oregon.

Rasmussen, Kent. 1998. "Reduplication as the marker for plurality in Il-Wuasinkishu Maasai second person non-perfective verbs." Ms., University of Oregon.

Rasmussen, Kent. In preparation. "Transitivity effects on Class II tone patterns in Maasai verbs." Ms., University of Oregon.

Schröder, Martin. 1989. "The Toposa verb in narrative discourse." Africanistische Arbeitspapiere 20: 129-142.

Snider, Keith. 1999. The Geometry and Features of Tone. Arlington, TX: SIL and UT Arlington.

Stevick, Earl W. 1969. "Tone in Bantu." International Journal of American Linguistics 35: 330-341.

Tucker, Archibald. N. and J. Tompo Ole-Mpaayei. 1955. A Maasai Grammar with Vocabulary. New York and London: Longmans, Green and Co.

Wallace, Barbara F. 1981. "The morphophonemics of the Maasai verb." In Thilo C. Schadeberg and M.Lionel Bender (eds.), Nilo-Saharan: Proceedings of the First Nilo-Saharan Linguistics Colloquium, Leiden September 8-10, 1980. Foris: Dordrecht. Pp. 75-88.

Wallace-Gadsen, Barbara F. 1983. "/a/ within the system of Maasai vowel harmony." CUNY Forum 9: 21-40.

P.O. Box 3893

Eugene, OR 97403

kent-kim_rasmussen@sil.org
[Received August 2001; accepted October 2001] 
